\title{
印象採得法の基礎的検討
}

\author{
第 2 報 トレーのスペーサーとベントについて
}

星野亭

\section{Fundamental Studies of Impression Method \\ Part 2. Spacer and Vent in Impression Tray}

\section{Tohru Hoshino}

\section{第 1 章 緒 言}

有床補緅学における印象採得法は，義歯調製の第一歩 で義歯の予後を左右し，その比重は大きく今日まで数多 くの研究がなされている. 特に, 被圧変位性を有する頡 粘膜を印象対象とするとき, その印象採得法の相違は, 義歯調製過程での作業模型の粘膜面形態に影響をおよぽ し，その程度により，調製された義歯の適合不良および 機能時の床下組織への障害などが考えられ基礎的および 臨床的に検討されている. 基礎的立場からは作業模型に 影響を与える印象圧と，その分布について検討したも $の^{1,2)}$ ，レオロジーで検討したもの ${ }^{3)}$ ，扩よび印象対象物 としての䫟粘膜の物理的性質について検討したもの ${ }^{4 \sim 16)}$ がある。臨床的立場からは各種印象材と，トレーを用い て印象採得時にトレー内に生じる圧を測定したもの ${ }^{17)}$, 各種印象材を用いて印象採得し, 作業模型の寸法精度に ついて検討したもの ${ }^{18,19)}$ および印象圧と頒粘膜形態との 関係を検討したもの 20 22) などがある.

しかし，それぞれの立場から検討されているにもかか わらず，印象採得については未だ明確な結論には至って いないようである。

著者ら ${ }^{23)}$ は床下組織に障害を与えず，機能を十分に発 揮できる総義歯を調製するには，無歯頡々堤をいかなる 状態で再現すべきかを基礎的立場から検討した．その結

日本大学大学院歯学研究科歯科臨床系専攻（指導：森谷良 彦 教授)

Nihon University Graduate School of Dentistry at Tokyo (Major in Prosthodontics), (Director: Prof. Yoshihiko Moriya, D.D.S., D.D.Sc.)

昭和 58 年 12 月 14 日受付

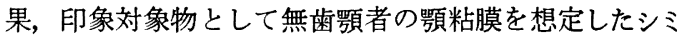
ユレーションモデルを製作し, その印象採得によって得 られた計測模型を三次元的に計測，比較する治具機構お よび計測対象物外に計測基準点を有する三次元位置再現 装置を考案開発し, 報告した ${ }^{23)}$.

そこで, 本研究では総義歯調製過程における印象採得 を想定し，顎堤であるシミュレーションモデルを用い て, トレー (スペーサー, ベント) および印象材などの 組合せを変え, それぞれの因子がシミュレーションモデ ルの再現性に及ぼす影響を三次元座標測定機で計測し, 基礎的に検討したので報告する.

\section{第 2 章 材料および方法}

\section{I. シミュレーションモデル}

印象の対象物は, 第 1 報 ${ }^{23)}$ の無歯買䫝粘膜を想定した 8 種のシミュレーションモデルからシミュレーションモ デル A-3 タイプ (以下, モデル A-3 と略す) とシミュ レーションモデルCタイプ (以下，モデルCと略す）お よびコントロールとしてシミュレーションモデル G夕イ プ (以下, モデル G と略す) の計 3 種を用いた (図 1). モデル A-3 は, 嚬骨に相当したエポキシレジンに頼粘膜 としてウレタンラバーを厚さ $3.0 \mathrm{~mm}$ で均一となるよう 接着したもの, モデルCはエポキシレジンを同心円の凸 状に成型し, 厚さ 3.0 と $2.0 \mathrm{~mm}$ のウレタンラバーであ る.これらモデル A-3 および C と比較検討するために, モデル $\mathrm{G}$ は顎粘膜としてのウレタンラバーを接着せず平 滑なエポキシレジンのみである，また，各ウレタンラバ 一厚さにおける常用荷重量 ${ }^{10)}$ 下での局所被圧変位量 ${ }^{10)}$ 表 1 に示した. 


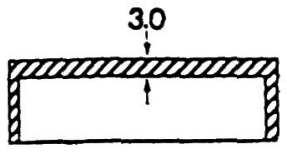

モデル $\mathrm{A}-3$

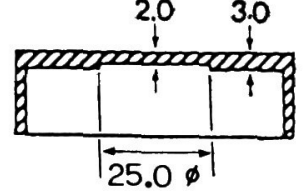

モデル C

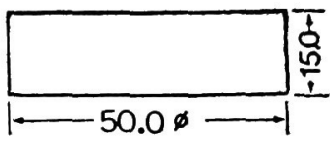

モデル G

U: Urethane rubber $\square$ : Epoxy resin

図 1 シミュレーションモデル

表 1 ウレタンラパーの被圧変位量

\begin{tabular}{ccc}
\hline$\overline{\text { ラバー暦さ }}$ & Mean & SD \\
\hline 2.0 & 0.82 & 0.12 \\
3.0 & 1.10 & 0.08 \\
\hline
\end{tabular}

unit : mm

常用荷重量：68 $\mathrm{mm}^{2}$

\section{II. 印象採得}

印象採得は 3 種のシミュレーションモデルに対して, 4 種のトレーに 3 種の印象材を用いて, 三次元位置再現 装置と万能試験機（インストロン社, 1123 型）とで行っ た.

1. トレー

トレー（図 2) はステンレススチール製で，ストッパ 一とベントの有無から 4 種類作製した. スペーサー無し をトレーSP $(0)$ ，ストッパー（長さ $10.0 \times$ 幅 $10.0 \times$ 厚 さ $2.0 \mathrm{~mm})$ 板を対称的に 4 力所設け，スペーサー 2.0 $\mathrm{mm}$ を付与したものをトレー SP (2) とした. これらに ついて, ベント無しをトレーV $\mathrm{V}(-)$, ベント（直径 2.5 $\mathrm{mm}$ )を $2.5 \mathrm{~mm}$ 間隔でトレーの上および周縁部に設け たベント有りをトレーV $\mathrm{V}(+)$ とした。

2. 印象材および模型材 印象材はアルジネート印象材 (以下, ALG と略す), ポリサルファイドラバー印象材（以下, RUB と略す）お よぴビニルシリコーン印象材（以下，SIL と略す）をエ ルコミックス（エルコデント社, TYPE 2) にて練和し， 模型材はコンビネーションユニット（ウィップミックス 社, MODEL-D) にて真空練和して用いた（表 2). 印象 材の使用に関し, ALG でテクニコールボンド (而至社), RUB および SIL では専用の接着剤を使用した。

3. 印象採得および計測模型

シミュレーションモデル上面とトレー上面とが平行と なるように, 万能試験機のロードセル部に三次元位置再
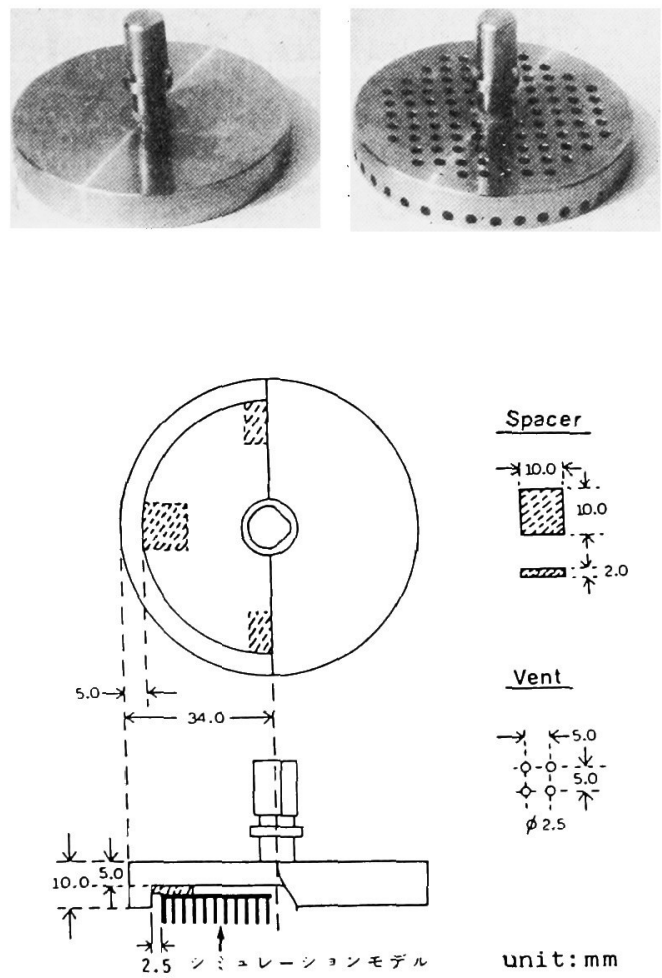

図 2 トレーおよびその䉿造図

現装置のヘッド上部を連結し，このへッド下部にトレー を設定した（図3)。つぎに，シミュレーションモデル上 方 $27.0 \mathrm{~mm}$ のトレーに印象材 (表2) 点盛り,さらにシ ミュレーションモデル上面にも塗りつけ, トレー圧接速 度 $100 \mathrm{~mm} / \mathrm{min}$. でシミュレーションモデル $2.0 \mathrm{~mm}$ 上 方まで圧接し，その後，直ちにトレーを圧接速度 0.05 $\mathrm{mm} / \mathrm{min}$, $0.51 \mathrm{~g} / \mathrm{mm}^{2}$ (1.0 kgf) の保持压で印象材の硬 
表 2 実験に用いた印象材と模型材

\begin{tabular}{|c|c|c|c|c|c|c|}
\hline 略号 … & 製 品 & 製造会补名 & 製造番号 & 使用条作 & 牛（練和時間） & \\
\hline ALG & ALGIACE POWDER & Sankin Mfg. & $117-344$ & Water/Powder & $33.6 \mathrm{ml} / 15 \mathrm{~g}$ & $(45 \mathrm{sec})$ \\
\hline RUB & SURFLEX-F Regular type & G-C Mfg. & 201011 & Base/Catalist & $10 \mathrm{~g} / 15 \mathrm{~g}$ & $(45 \mathrm{sec})$ \\
\hline SI L & EXAFLEX Regular Type & G-C Mfg. & 030331 & Base Catalist & $12 \mathrm{~g} / 12 \mathrm{~g}$ & $(30 \mathrm{sec})$ \\
\hline
\end{tabular}

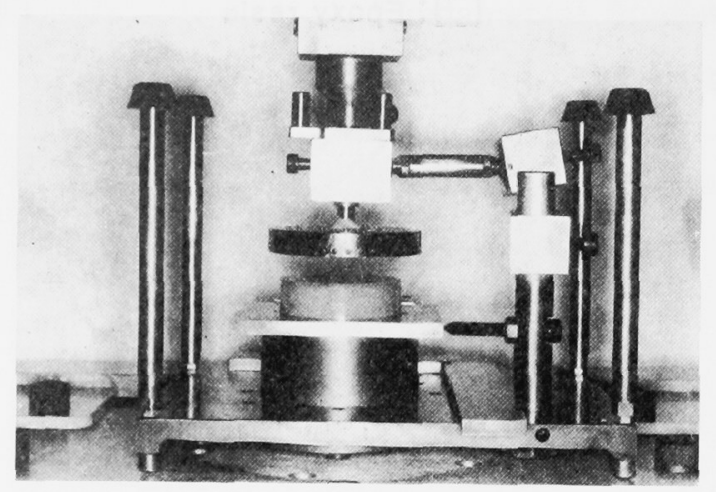

図 3 各装置の位置関倸

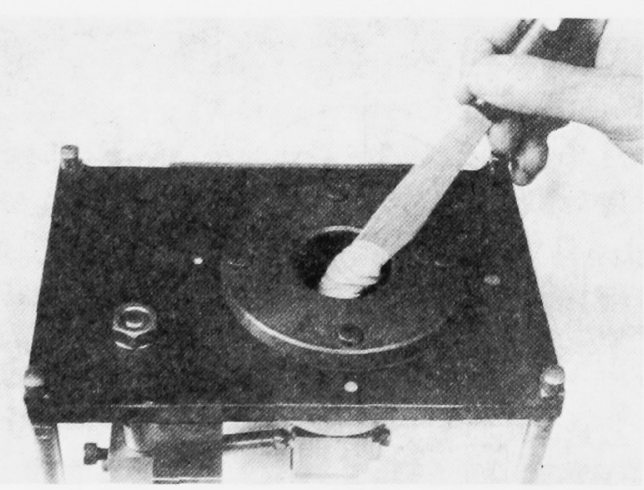

図 4 模型材の注入

化 (ALG で6 分, RUB で 20 分, SIL で 10 分) まで保持 した.

印象材の硬化後, 三次元位置再現装置のアーム各部を ロックし，万能試験機より取り外した. そして，三次元 位置再現装置のヘッド部と基底部からトレーとシミュレ ーションモデルを一体として取り外し，エアーシリンジ を用いてトレーとシミュレーションモデルを分離し, ト レーのみをヘッド部に再付着した.さらに，計測模型用 座金を取り付け，基底部から模型材をバイブレーター （而至社，R-II）使用して注入し（図 4), 相対湿度 100\% 下で硬化させ計測模型を作製した (図 5). 計測模型は各 印象条件につき 5 個ずつ，計 180 個作製した。なお，印

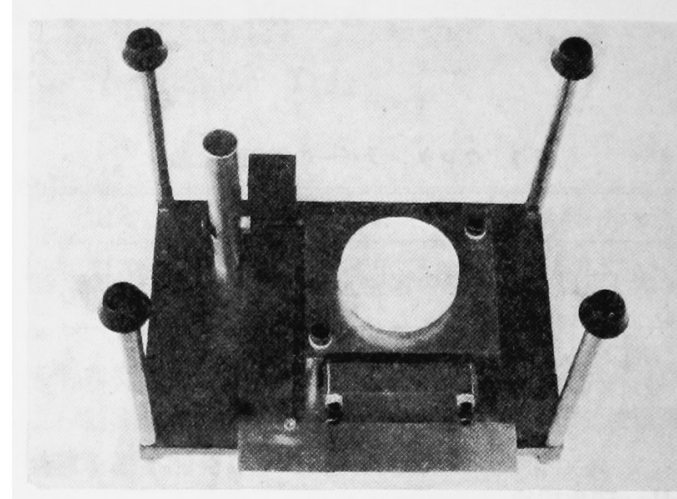

図 5 三次元位置再現装置と計測模型

象採得および計測模型の作製は温度 $23 \pm 2^{\circ} \mathrm{C}$, 相対湿度 $50 \pm 10 \%$ の環境下で行った.

\section{III. 計測方法}

1. 計測基準の設定

計測には三次元座標測定機 22 31) (東京精密社, XY ZAX, M-400) にミニコンピュータ（日本データゼネラ ル社, NOVA-4C 型) を組合わせたシステムを用いた.

シミュレーションモデルおよび計測模型外に計測基準 を設定するため，三次元位置再現装置の本体表面に L 字 型の基準平面板（図 6-I）を取り付け，三次元座標测定 機の計測基隻とした.

計測基準は図 7 に示すごとく，基準平面板上の $\mathrm{Z1}$, $\mathrm{Z} 2, \mathrm{Z3}$ から $\mathrm{XY}$ 平面を決定し, さらに $\mathrm{Y} 1, \mathrm{Y} 2$ を通り $\mathrm{XY}$ 平面と垂直に $\mathrm{XZ}$ 平面を定め, これら 3 平面からミ ニコンピュータ (NOVA-4C) にて X 軸, $\mathrm{Y}$ 軸, Z 軸およ び原点を定めた．これら計測基準軸および原点の設定は シミュレーションモデルおよび計測模型の計測時ごとに 行い, 設定に際しては一定の接触圧により作動する電子 プローブ (東京精密社, TP-1, フィーラ先端半径 500 $\mu \mathrm{m})$ を使用した. 三次元座標測定機を用いて計測時ごと に計測基準軸と原点を設定して行うので，この原点のく り返し再現精度としての標準偏差は X, Y 方向で $4 \mu \mathrm{m}$ およびZ方向で $3 \mu \mathrm{m}$ であった. 

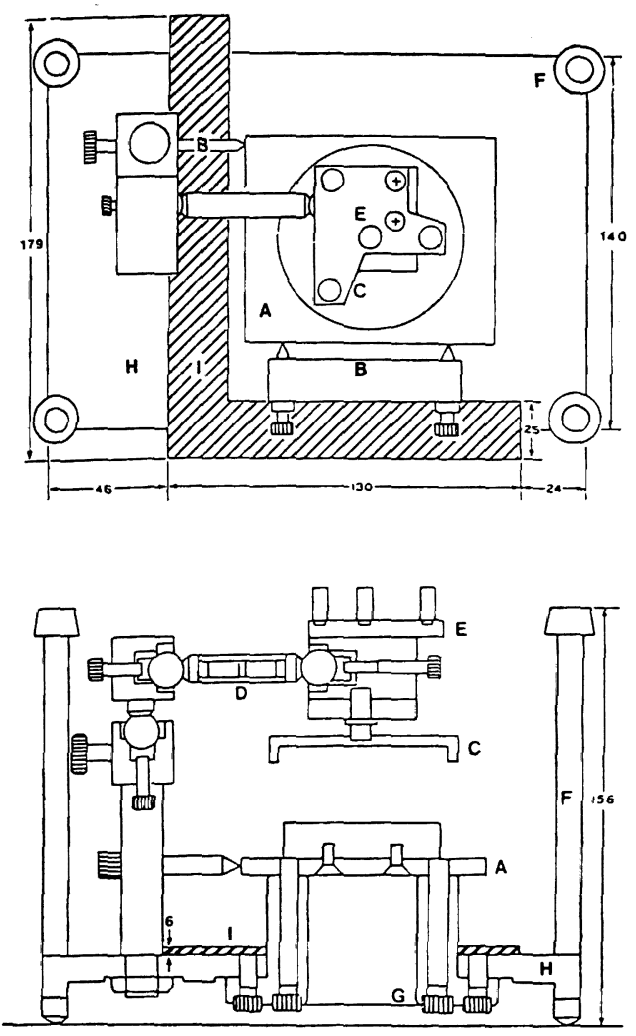

unit: $\mathrm{mm}$

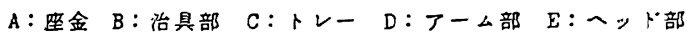
$\mathrm{F}:$ スント $\mathrm{G}:$ 底部 $\mathrm{H}:$ 本体部 $\mathrm{I}:$ 集平面板

図 6 三次元位置再現装置の構造図 上: 上面観 下 : 侧面観

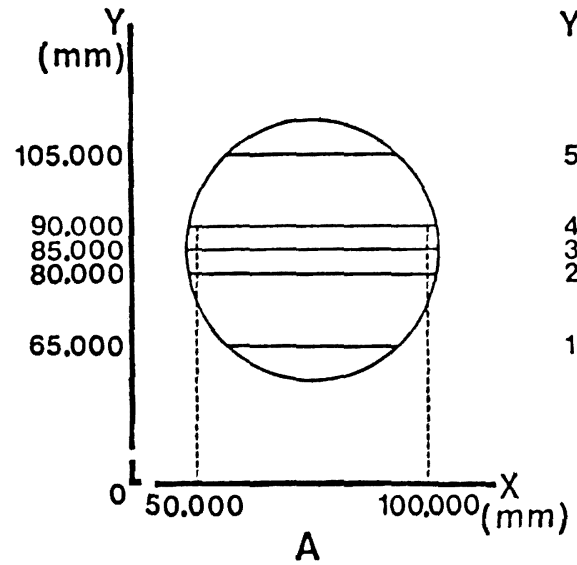

图 8 計測断面(A)と標点(B)
なお，計測基準の設定および計測は温度 $23 \pm 1^{\circ} \mathrm{C}$, 相 対湿度 $50 \pm 5 \%$ の環境下で行った。

2. 計測

計測は第 1 報に従い，座金上に固定されたシミュレー ションモデルあるいは計測模型を三次元位置再現装置の 治具部（図 6-B）に付着し，設定された計測基準軸と原 点からの位置関係を第 1 報（座金取りはずし前と後にお いて, $\mathrm{X}, \mathrm{Y}$ 扰よび $Z$ 方向の $\mathrm{SD}=0.001 〜 0.004$ である) に示すごとく，高精度に確保して行う.

計測断面は $\mathrm{Y}=65.000$ から 105.000 までの $5 \mathrm{Y}$ 断面 に拉いて, $X$ 方向 $1.0 \mathrm{~mm}$ ピッチで行い (図 8-A), 各 $\mathrm{Y}$ 断面につき $X=50.000$ から 100.000 までを $5.000 \mathrm{~mm}$ ピッチでミニコンピュータにより算出した $Z$ 座標值を求 めた (図 8-B). 以後, $\mathrm{X}$ 断面の $\mathrm{X}=50.000$ を $\mathrm{X} 1, \mathrm{X}=$

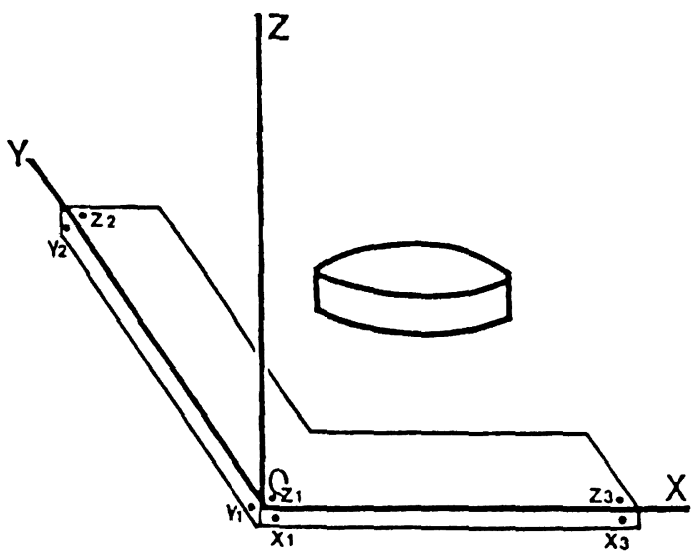

图 7 詶测基淮の没定

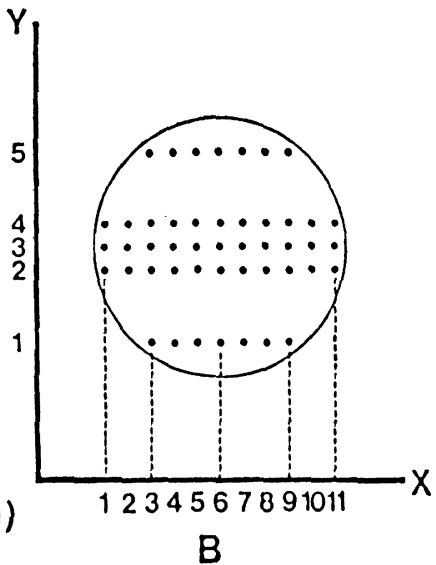

B 
表 3 シミュレーションモデルの各Y断面における 計測値 (モデル $\mathrm{G}$ )

\begin{tabular}{rccc}
\hline \hline $\mathrm{X}$ & \multicolumn{3}{c}{$\mathrm{Y}$} \\
\cline { 2 - 4 } & 3 & 4 & 5 \\
\hline 1 & $44.348(0.001)$ & $44.336(0.001)$ & \\
2 & $44.389(0.001)$ & $44.375(0.001)$ & \\
3 & $44.428(0.001)$ & $44.413(0.001)$ & $44.332(0.000)$ \\
4 & $44.461(0.001)$ & $44.448(0.000)$ & $44.355(0.000)$ \\
5 & $44.486(0.000)$ & $44.473(0.001)$ & $44.377(0.001)$ \\
6 & $44.503(0.001)$ & $44.491(0.001)$ & $44.394(0.000)$ \\
7 & $44.511(0.000$ & $44.499(0.001)$ & $44.401(0.001)$ \\
8 & $44.509(0.001)$ & $44.496(0.001)$ & $44.400(0.001)$ \\
9 & $44.4980 .000)$ & $44.485(0.000)$ & $44.401(0.001)$ \\
10 & $44.4810 .001)$ & $44.466(0.001)$ & \\
11 & $44.475(0.003)$ & $44.461(0.002)$ & \\
\hline
\end{tabular}

unit : mm

( ) : SD

55.000 を $\mathrm{X} 2, \cdots \cdots \mathrm{X}=100.000$ を $\mathrm{X} 11$ に, $\mathrm{Y}$ 断面の $\mathrm{Y}=$ 65.000 を $\mathrm{Y} 1, \mathrm{Y}=80.000$ を $\mathrm{Y} 2, \cdots \cdots \mathrm{Y}=105.000$ を $\mathrm{Y} 5$ と図 8 に示すごとく略した。

1) シミュレーションモデル

計測時, 三次元座標測定機の電子プローブは垂直方向 で約 $40 \mathrm{gf}$ の接触圧があり，シミュレーションモデルの 顎粘膜となるウレタンラバーに変位が予測される，その 変位を避けるため, 導電性樹脂ドータイト（藤倉化成社， D-500）をエアーブラシでシミュレーションモデル表面 に噴霧し，プローブのフィーラとシミュレーションモデ ル表面に電極を貼り，フィーラとシミュレーションモデ ルとの接触による電気的導通を電気的信号として, 三次 元座標測定機からミニコンピュータに入力し, 計測值を 求めた。使用したドータイトの平均被膜厚さは $14 \mu \mathrm{m}$ であった。

\section{2) 計測模型}

模型材注入 12 時間後, 三次元位置再現装置上の 計 測 模型はシミュレーションモデルと同断面で計測した．計 測の結果, 各印象条件において Y3 断面を対称軸として 対応する $\mathrm{Y} 1$ と $\mathrm{Y} 5$ および $\mathrm{Y} 2$ と $\mathrm{Y} 4$ の間に, $\mathrm{t}$ 検定でそ れぞれ有意差 $(\alpha=0.05)$ が認められなかったため，Y3， Y4 および Y5 の 3 断面について計测検討することとし た.

\section{第 3 章 成 績}

無歯顎々粘膜を想定したシミュレーションモデルの印 象採得によって得られた計測模型を, 三次元位置再現装
28 巻 2 号 (1984)

表 4 シミュレーションモデルの各Y断面における 計測值（モデル A-3）

\begin{tabular}{rccc}
\hline \hline $\mathrm{X}$ & 3 & $\mathrm{Y}$ & \\
\cline { 2 - 4 } & 3 & 4 & 5 \\
\hline 1 & $44.572(0.003)$ & $44.566(0.004)$ & \\
2 & $44.603(0.005)$ & $44.593(0.003)$ & \\
3 & $44.640(0.003)$ & $44.626(0.003)$ & $44.527(0.008)$ \\
4 & $44.668(0.004)$ & $44.648(0.004)$ & $44.534(0.008)$ \\
5 & $44.677(0.002)$ & $44.659(0.002)$ & $44.540(0.006)$ \\
6 & $44.685(0.003)$ & $44.656(0.004)$ & $44.537(0.006)$ \\
7 & $44.687(0.005)$ & $44.662(0.004)$ & $44.532(0.008)$ \\
8 & $44.676(0.008)$ & $44.642(0.003)$ & $44.538(0.008)$ \\
9 & $44.640(0.005)$ & $44.616(0.002)$ & $44.503(0.007)$ \\
10 & $44.605(0.002)$ & $44.581(0.004)$ & \\
11 & $44.553(0.004)$ & $44.504(0.005)$ & \\
\hline
\end{tabular}

unit : mm

( ) : SD

表 5 シミュレーションモデルの各Y断面における 計測值 (モデルC)

\begin{tabular}{rccc}
\hline \hline $\mathrm{N}$ & \multicolumn{3}{c}{$\mathrm{Y}$} \\
\cline { 2 - 4 } & 3 & 4 & 5 \\
\hline 1 & $44.665(0.001)$ & $44.632(0.007)$ & \\
2 & $44.717(0.005)$ & $44.671(0.002)$ & \\
3 & $44.745(0.003)$ & $44.707(0.005)$ & $44.516(0.005)$ \\
4 & $44.757(0.005)$ & $44.712(0.004)$ & $44.533(0.001)$ \\
5 & $44.748(0.003)$ & $44.720(0.006)$ & $44.545(0.003)$ \\
6 & $44.749(0.007)$ & $44.715(0.004)$ & $44.546(0.003)$ \\
7 & $44.746(0.005)$ & $44.722(0.007)$ & $44.549(0.004)$ \\
8 & $44.734(0.006)$ & $44.706(0.006)$ & $44.541(0.007)$ \\
9 & $44.716(0.004)$ & $44.683(0.002)$ & $44.505(0.001)$ \\
10 & $44.673(0.003)$ & $44.649(0.003)$ & \\
11 & $44.616(0.001)$ & $44.602(0.003)$ & \\
\hline
\end{tabular}

unit : mm

$: \mathrm{SD}$

置と三次元座標測定機を用いて計測を行った結果，以下 の成績を得た。

各Y断面について，シミュレーションモデル（モデル $\mathrm{G}$ ，モデル A-3 およびモデル C) と印象採得により得ら れた計測模型との差を $Z$ 軸に示し, $X$ 軸に $X 1 〜 11$ を 示した（図 9〜11）.

I. モデル G（表 3，6，7，および図 9）

表 3 に示すごとく, モデル $\mathrm{G}$ の各Y断面は X6〜8 大きく，その両側で徐々に小となる傾向を示した.

ALG による計測模型（図 9) の Y3 および Y4 におい て，各トレーは X5〜7 を頂としたゆるやかな凸状を示 すが, Y5 断面において X3 から 9 までほぼ平坦であっ た. 計測模型の各Y断面において, トレーSP (2) V 


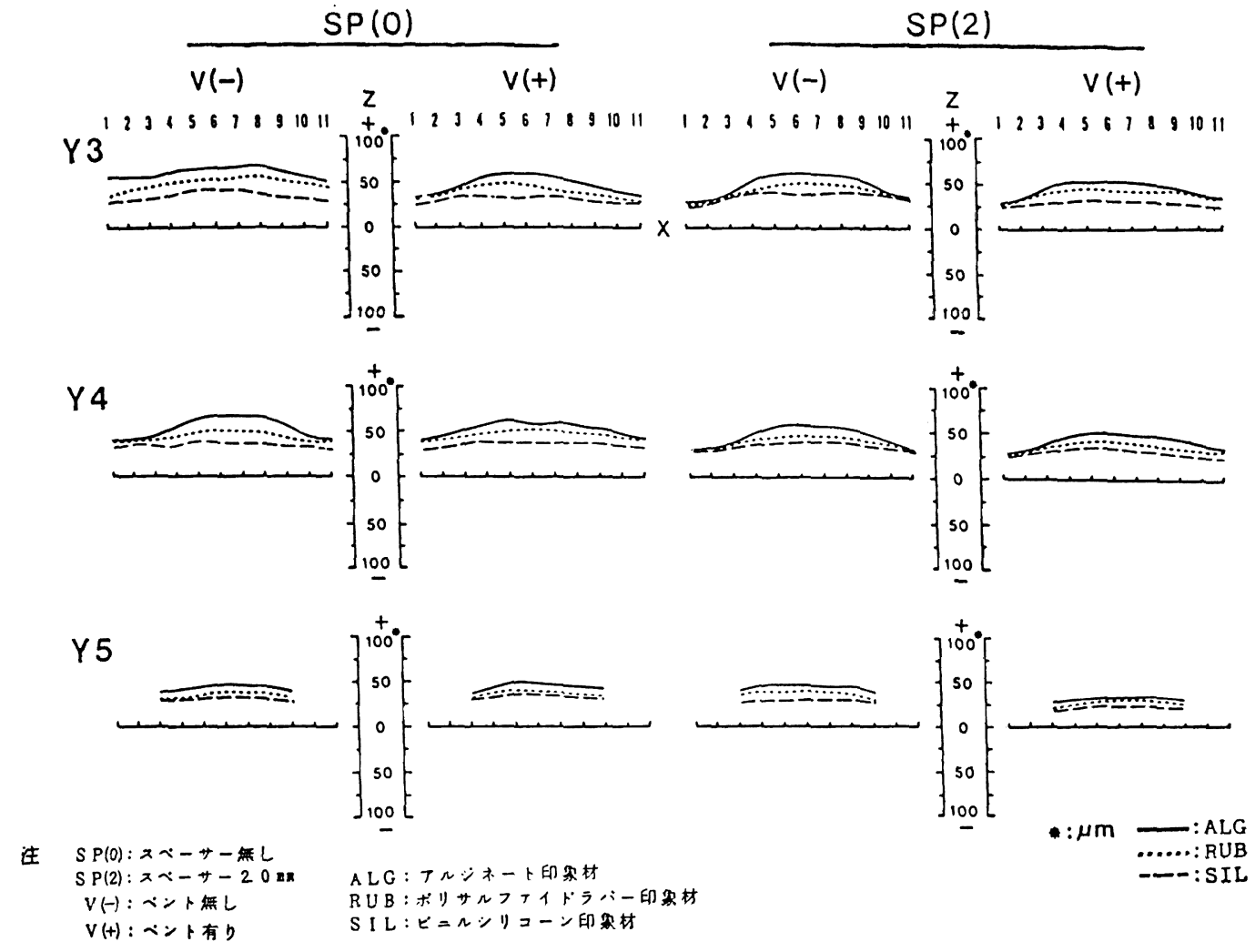

図 9 計测模型の各Y断面における成績（モデル G)

(十) が最も小さく(約 $30 \mu \mathrm{m})$, トレー SP (2) V (一), トレーSP (0) V (十), トレーSP (0) V (一) の順に大 きくなる傾向を示した.

RUB による計測模型（図 9) の各 Y 断面において，各 トレーは ALG とほぼ同じ傾向を示すが, ALGよりもゆ るやかな凸状を示した。計測模型の各Y断面において， トレーSP (2) V (十) が最も小さく（約 $25 \mu \mathrm{m}$ ), ALG とほぼ同じ傾向を示した。

SIL による計測模型（図 9) の各 Y 断面において，各 トレーは RUB よりもさらに平坦となり，ほとんど凸状 を示さなかった. 計測模型の各Y断面において，各トレ 一はほぼ同じ值 (25〜30 $\mu \mathrm{m})$ を示した.

各印象材についてトレー間で $\mathrm{t}$ 検定を行った結果， $\mathrm{Y}$ 断面でそれぞれ有意差 $(\alpha=0.05)$ を認めなかった（図 6).

各トレーについて印象材間で $\mathrm{t}$ 検定を行った結果（表 7)，それぞれ有意差（ $\alpha=0.05 ）$ を認めなかった.

II. モテル $\mathrm{A}-3$ (表 4，8，9，図 10，12 および 13） 表 4 に示すごとく，モデル A-3 の各 $\mathrm{Y}$ 断面は $\mathrm{X} 4$ 〜 7
で大きくそその両側で徐々に小となる傾向であった。

ALGによる計測模型（図 10）の Y3 および Y4 断面に おいて，トレーSP (2) V (十) は X3〜9で X5〜7 頂 とする著明なら状 (約 $20 \mu \mathrm{m}$ ) を示すが, X3 から X1 お よび X9 から X11 となるに従い著明な凹状（約 -35 $\mu \mathrm{m})$ を示した。しかし，他のトレーはほぼ平坦であり， トレー SP (2) V (一) が最も小さく（約 $35 \mu \mathrm{m}$ ), トレ 一 SP (0) V (一) とトレーSP (0) V (十) はほぼ同程 度であった. Y5 断面において,トレー SP (2) V (十)は $\mathrm{X} 6$ を最深としたV字形な凹状（約 $-35 \mu \mathrm{m} ）$ を示した が, X3，4,8 および 9 でほぼ平坦（約 $5 \mu \mathrm{m}$ ) であった.

トレー SP (2) V (一) が最も小さく(約 $10 \mu \mathrm{m})$, トレ - SP (0) V (十) とトレーSP (0) V (一) はほぼ同程 度であった。

RUB による計測模型（図 10）は ALG とほぼ同じ傾 向を示し, Y3 および Y4 断面において, トレー SP (2) $\mathrm{V}$ (十) は X3〜9 で X5〜7 を頂とする著明な凸状（約 $30 \mu \mathrm{m})$ を示すが, X3 から X1 および X9 から X11 とな るに従い著明な凹状（約 $-35 \mu \mathrm{m} ）$ を示した。しかし， 
表 6 各種印象材におけるトレー間の $\mathrm{t}$ 検定（モデル $\mathrm{G}$ )

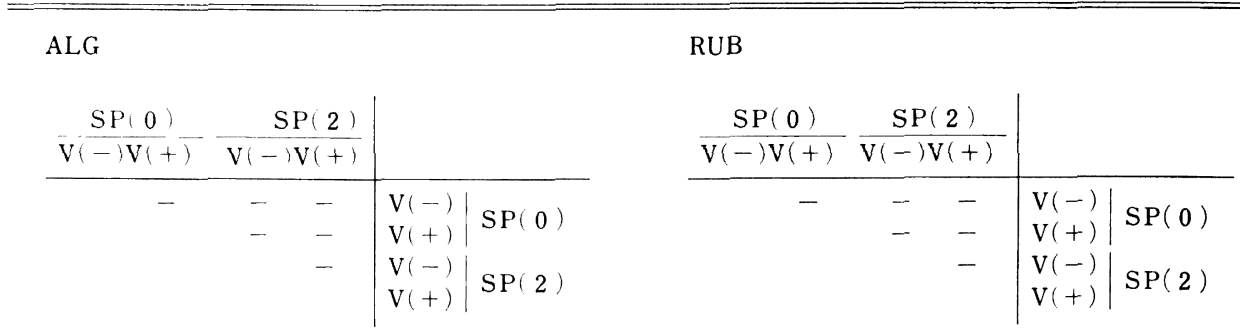

SIL

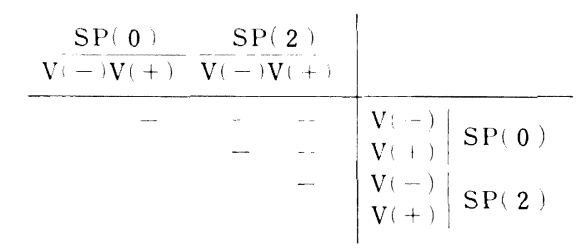

\begin{tabular}{|c|c|c|}
\hline ii: : SP(0)：スペーサー無し & ALG：アルジネート印象材 & 一：有意差無し $(\alpha=0.05)$ \\
\hline $\mathrm{SP}(2):$ スベーサー $-2.0 \mathrm{~mm}$ & RUB：ボリサルファイドラハー一印爱性 & + ：有意差有り $(\alpha=0.05)$ \\
\hline $\begin{array}{l}\mathrm{V}(-1: \text { ヘンント無し } \\
\mathrm{V}(+): \text { ベント们り }\end{array}$ & SIL：ピニルシリコーン卵熋恍 & \#：有意差有） $(\alpha=0.01 ）$ \\
\hline
\end{tabular}

表 7 各種トレーにおお抑象材間の $\mathrm{t}$ 検定 (モデル $\mathrm{G}$ )

\begin{tabular}{|c|c|c|c|c|c|c|c|}
\hline \multicolumn{4}{|c|}{$\mathrm{SP}(0) \mathrm{V}(-)$} & \multicolumn{4}{|c|}{$\mathrm{SP}(2) \mathrm{V}(-)$} \\
\hline$A L G$ & $R U B$ & S I L & & A L G & $\mathrm{RUB}$ & S I L & \\
\hline & - & - & $\begin{array}{l}\text { A LG } \\
R \cup B \\
S I L\end{array}$ & & - & - & $\begin{array}{l}\text { A L G } \\
\text { RUB } \\
\text { S I L }\end{array}$ \\
\hline \multicolumn{4}{|c|}{$\mathrm{SP}(0) \mathrm{V}(+)$} & \multicolumn{4}{|c|}{$\mathrm{SP}(2) \mathrm{V}(+)$} \\
\hline $\mathrm{ALG}$ & RUB & S I L & & ALG & RUB & S I L & \\
\hline & - & - & $\begin{array}{l}\text { A LG } \\
\text { RUB } \\
\text { S I L }\end{array}$ & & - & - & $\begin{array}{l}\text { A L G } \\
\text { RUB } \\
\text { S I L }\end{array}$ \\
\hline \multicolumn{4}{|c|}{ 拄：表6下注䒯照 } & & \multicolumn{3}{|c|}{ 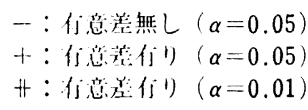 } \\
\hline
\end{tabular}

他のトレーはほぼ平坦であり,トレーSP (2) V (一)が 最む小さく（約 $35 \mu \mathrm{m}$ ), トレー SP (0) V (一) とトレ 一 SP (0) V (十) はほぼ同程度であった. Y5 断面にお いても，トレーSP (2) V (十)は X6 を最深としたV字
形な凹状 (約 $-35 \mu \mathrm{m}$ ) を示したが, X3〜 5 および X7〜 9 でほぼ平坦 (約 $15 \mu \mathrm{m}$ ) であった. トレー SP (2) V (一) が最も小さく(約 $50 \mu \mathrm{m})$, トレーSP (0) V (-), トレー SP (0) V (十) はほぼ同程度であった. 
表 8 各種印象材におけるトレー間の $\mathrm{t}$ 検定（モデル $\mathrm{A}-3$ )

\begin{tabular}{|c|c|c|c|c|c|c|c|}
\hline \multirow{2}{*}{$\begin{array}{l}\text { ALG } \\
\qquad \mathrm{SP}(0)\end{array}$} & \multicolumn{7}{|c|}{ RUB } \\
\hline & $\mathrm{SP}(2)$ & & & $\mathrm{SP}(0)$ & $\mathrm{SP}(2)$ & & \\
\hline$\overline{\mathrm{V}}(-) \mathrm{V}(+)$ & $\mathrm{V}(-\mathrm{V}(+)$ & & & $\mathrm{V}(\cdots) \mathrm{V}(+)$ & $\mathrm{V}(-) \overline{\mathrm{V}}(+)$ & & \\
\hline- & $\begin{array}{ll}- & + \\
- & + \\
-\end{array}$ & $\begin{array}{l}\mathrm{V}(-) \\
\mathrm{V}(+) \\
\mathrm{V}(-) \\
\mathrm{V}(+)\end{array}$ & $\begin{array}{l}\operatorname{SP}(0) \\
\operatorname{SP}(2)\end{array}$ & - & $\begin{array}{l}-\quad H \\
-\quad H \\
-\end{array}$ & $\begin{array}{l}\mathrm{V}(-) \\
\mathrm{V}(+) \\
\mathrm{V}(-) \\
\mathrm{V}(+)\end{array}$ & $\begin{array}{l}\operatorname{SP}(0) \\
\operatorname{SP}(2)\end{array}$ \\
\hline
\end{tabular}

SIL

\begin{tabular}{|c|c|c|c|}
\hline $\mathrm{SP}(0)$ & \multirow{2}{*}{$\frac{\mathrm{SP}(2)}{\mathrm{V}(-) \mathrm{V}(+)}$} & & \\
\hline $\mathrm{V}(-) \mathrm{V}(+)$ & & & \\
\hline - & $\begin{array}{ll}- & H \\
- & H \\
& -\end{array}$ & $\begin{array}{l}\mathrm{V}(-) \\
\mathrm{V}(+) \\
\mathrm{V}(-) \\
\mathrm{V}(+)\end{array}$ & $\begin{array}{l}\mathrm{SP}(0) \\
\mathrm{SP}(2)\end{array}$ \\
\hline
\end{tabular}

注：表 6 下注参照

SIL による計測模型の各Y断面において，各トレーは RUB とほとんど同じ傾向を示した.

各印象材についてトレー間で $\mathrm{t}$ 検定を行った結果（表 8), ALG においてトレーSP (0) V (一) およびトレー $\mathrm{SP}(0) \mathrm{V}(+)$ はトレー SP (2) V (十) と図 12 に示し たY断面で有意差 $(\alpha=0.05,0.01)$ を認めた。 これらの トレー間における平均値の差は 80〜85 $\mu \mathrm{m}$ であった（図 10). RUB および SIL において（表 9), トレー SP (0) V (一) およびトレー SP (0) V (十) はトレー SP (2) V (+) と図 13 に示した Y 断面で高度の有意差 $(\alpha=0.01)$ を認めた.これらのトレー間におけるその差は80〜85 $\mu \mathrm{m}$ であった（図 10）.

各トレーについて印象材間で $\mathrm{t}$ 検定を行った結果（表 9), 各 Y 断面においてそれぞれ有意差（ $\alpha=0.05 ）$ を認 めなかった。

III. モデル C (表 5, 10, 11, 図 11 および 14)

表 5 に示すごとく，モデルCの各Y断面は X5〜8 で 大きく，その両側で徐々に小となる傾向であった.

ALG による計測模型（図 11）の Y3 および Y4 断面 において，トレー SP (2) V (一) とトレー SP (2) V (十) は X3〜8 で X4〜6 を頂とする著明な凸状 (40〜50
～：有意差無し $(\alpha=0.05)$

+ : 有意差有 $\left.{ }^{\prime}\right)(\alpha=0.05)$

井：有意差有り $(a=0.01)$ $\mu \mathrm{m})$ を示すが, X3 から X1 およびX9 から X11 となる に従い著明な凹状 $(-25 \sim-80 \mu \mathrm{m})$ を示した。 トレー $\mathrm{SP}(0) \mathrm{V}($ ( ) とトレーSP (0) V (十) は, トレーSP (2) $\mathrm{V}(+)$ よりも X4〜9 でゆるやかな凸状（10～20 $\mu \mathrm{m})$ を示し，また X3 から X1 および X9 から X11 と なるに従ってもゆるやかな凹状 $(-5 \sim-25 \mu \mathrm{m})$ を示し た. Y5 断面においてトレー SP (2) V (一) とトレー SP (2) V (十) は X6 を最深としたV字形な凹状 $(-25 〜-$ $80 \mu \mathrm{m})$ を示したが X3〜 5 および X7〜9 でほぼ平坦 $(0 \sim 15 \mu \mathrm{m})$ であった. トレーSP $(0) \mathrm{V}(-)$ とトレー $\mathrm{SP}(0) \mathrm{V}(+)$ は $3 \sim 9$ でほぼ平坦 $(0 \sim-15 \mu \mathrm{m})$ で あった。

RUB による計測模型（図 11）は ALG とほぼ同じ傾 向を示し，Y3 および Y4 断面に拉いて，トレー SP (2) $\mathrm{V}($ （）とトレー SP (2) V (十) は X3〜8 で X5 を頂と 寸る著明な凸状 $(65 〜 85 \mu \mathrm{m})$ を示すが，X3 から X1 お よび X9 から X11 となるに従い著明な凹状 $(-25 〜-80$ $\mu \mathrm{m})$ を示した. トレー SP (0) V (一) とトレーSP (0) $\mathrm{V}(+)$ は X2〜10 でトレー SP (2) V (十)よりもゆる やかな凸状 (25〜 40 $\mu \mathrm{m})$ を示し, X2 から X1 および X 10 から X11 となるに従ってもゆるやかな凹状（0〜-15 $\mu \mathrm{m})$ を示した. Y5 断面においてトレーSP (2) V (-) 


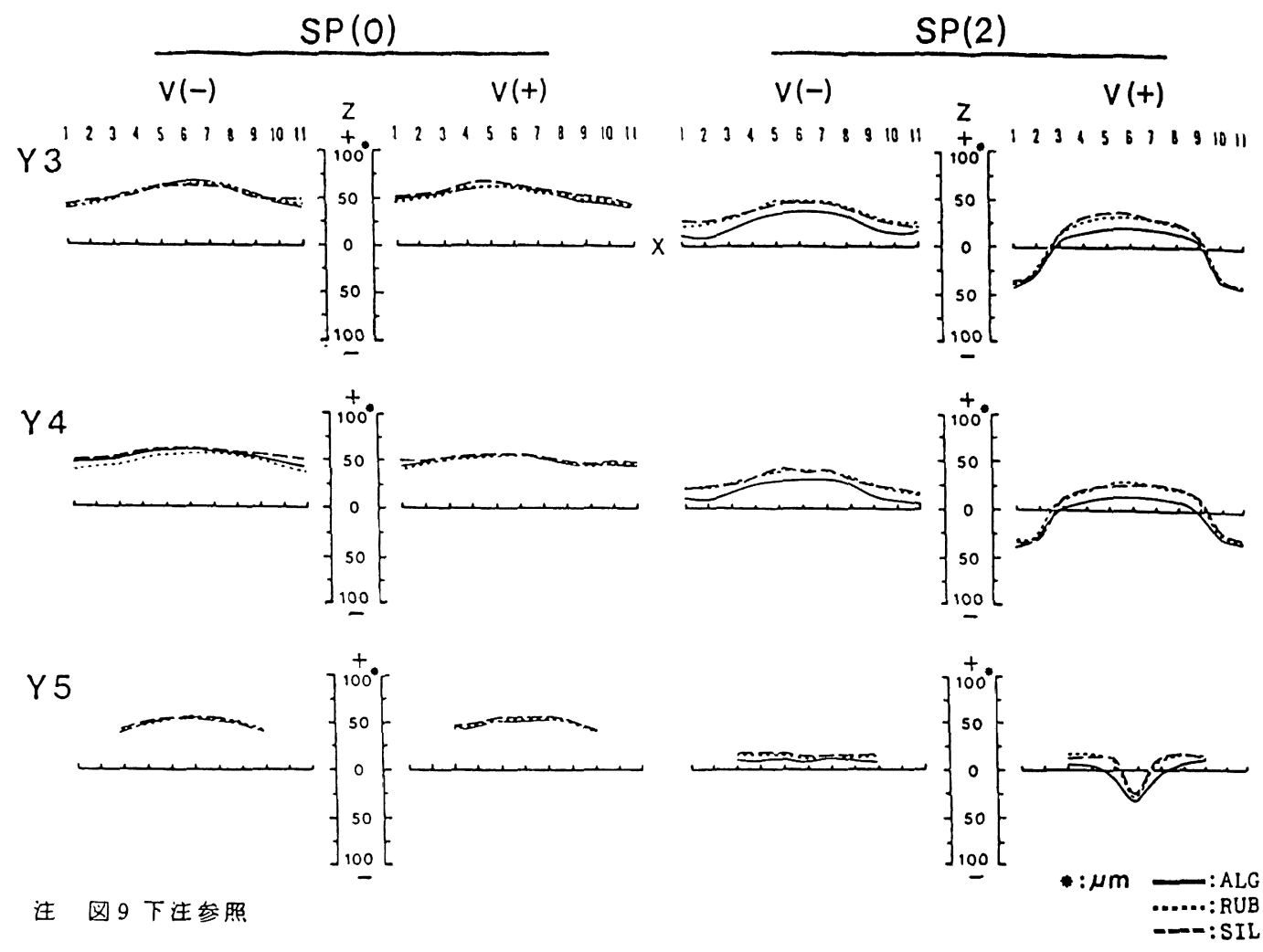

図 10 計測模型の各Y断面における成績（モデル A-3）

とトレーSP (2) V (十) はX6 を最深としたV字形な凹 状 $(-25 〜-80 \mu \mathrm{m})$ を示したが, X3〜 5 および X7〜9 でほぼ平坦 $(-10 \sim 5 \mu \mathrm{m})$ であった.トレーSP (0) V (一) とトレーSP $(0) \mathrm{V}(+)$ は X3〜9 でほぼ平坦（一 10〜 $5 \mu \mathrm{m})$ であった.

SIL による計測模型の各Y断面において，各トレーは RUB とほとんど同じ傾向を示した.

各印象材についてトレー閒で $\mathrm{t}$ 検定を行った結果（表 10), ALG においてそれぞれ有意差 $(\alpha=0.05)$ を認め なかった，RUB および SIL に拉て（表 10), トレー $\mathrm{SP}(0) \mathrm{V}($ （）およびトレー SP (0) V (十) はトレー SP (2) V (十) と図 14 に示した Y 断面で有意差 $(\alpha=$ 0.05)を認めた。これらのトレー間におけるその差は 70〜80 $\mu \mathrm{m}$ であった（図 11）.

各トレーについて印象材間で $\mathrm{t}$ 検定を行った結果（表 11), 各 Y 断面においてそれぞれ有意差 $(\alpha=0.05)$ を認 めなかった。

\section{第 4 章 総括および検討}

口腔内に装着された総義歯に加わる咬合力，および咀 嚼力は人工歯から義蒾床を介し頭堤（粘膜，顎骨）で負 担される．そのため，無歯顎々堤をいかなる状態で作業 模型に再現するかは，床下組織に障害を与えず，かつ機 能を十分に発揮できる総義歯を調製する上で重要なこと である．著者は無歯蕦々堤と顎粘膜を想定したシミュレ ーションモデル ${ }^{23)}$ と三次元位置再現装置 ${ }^{23)}$ を用いて，総 義歯調製過程における印象採得時に顎堤，トレーおよび 印象材の相違が計測模型におよぼす影響について三次元 的に検討した.

\section{I. 材料および方法について}

1. シミュレーションモデル

第 1 報で報告したなかより，ウレタンラバーをエポキ シレジンに接着したモデル A-3 とモデル C を選択した. しかしこれらの印象採得により調製した計測模型は印 

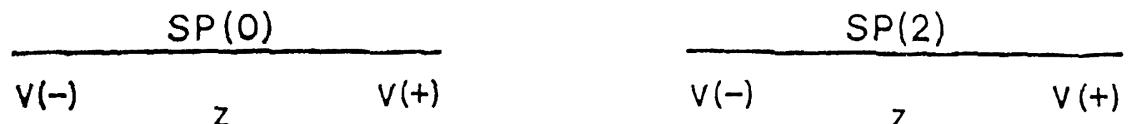

Y3

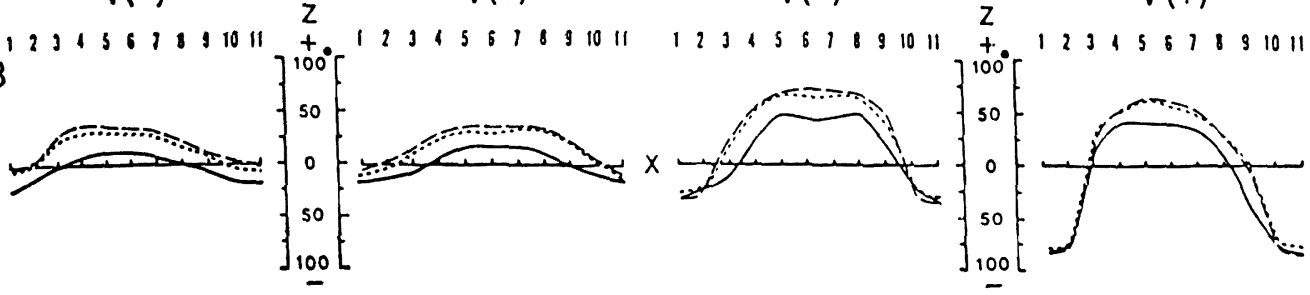

Y4
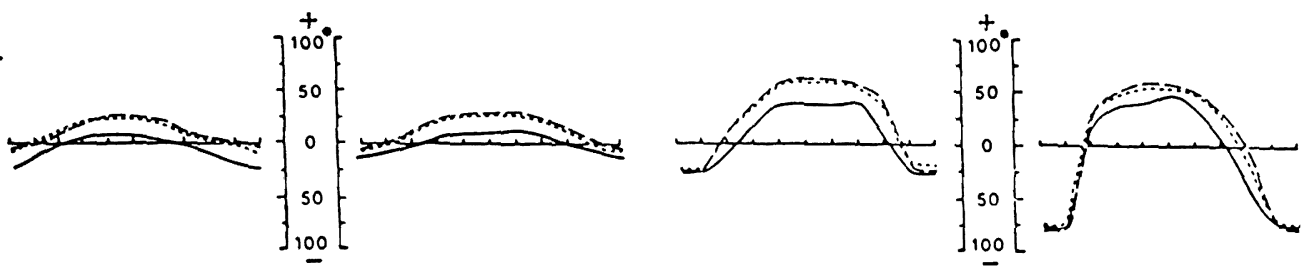

Y 5
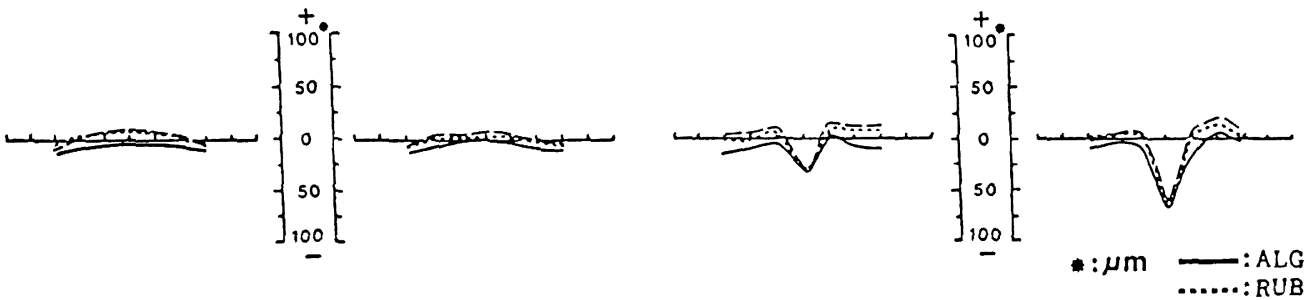

拄四9 下注参照

図 11 計測模型の各Y断面におう拈成績（モデルC）

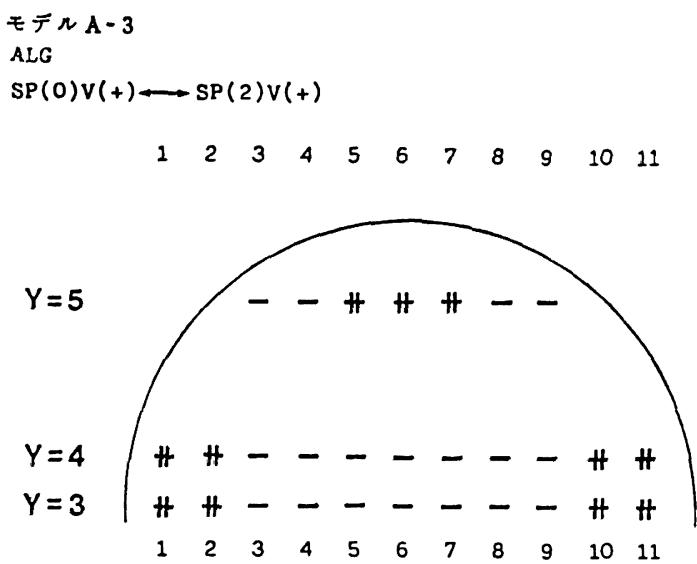

一:有意差無し $(\alpha=0.05)$

+ :有意差有り $(\alpha=0.05)$

拄図 9'下注参照

\#:有意差有b $(\alpha=0.01)$

図 12 トレーの組合せにより有意差を示した部位 
表 9 各種トレーにおける印象材間の $\mathrm{t}$ 検定（モデル $\mathrm{A}-3$ -

\begin{tabular}{|c|c|c|c|c|c|c|c|}
\hline \multicolumn{4}{|c|}{$\mathrm{SP}(0) \mathrm{V}(-)$} & \multicolumn{4}{|c|}{$\mathrm{SP}(2) \mathrm{V}(-)$} \\
\hline $\mathrm{ALG}$ & RUB & S I L & & A L G & RUB & S I L & \\
\hline & - & $\begin{array}{l}- \\
-\end{array}$ & $\begin{array}{l}A L G \\
R U \dot{B} \\
S I L\end{array}$ & & - & - & $\begin{array}{l}\text { A L G } \\
\text { RUB } \\
\text { S I L }\end{array}$ \\
\hline \multicolumn{4}{|c|}{$\mathrm{SP}(0) \mathrm{V}(t)$} & \multicolumn{4}{|c|}{$\mathrm{SP}(2) \mathrm{V}(+)$} \\
\hline A L G & RUB & S I L & & A L G & RUB & S I L & \\
\hline & - & - & $\begin{array}{l}\text { A L G } \\
R U B \\
S I L\end{array}$ & & - & - & $\begin{array}{l}\text { A L G } \\
\text { R UB } \\
\text { S I L }\end{array}$ \\
\hline \multicolumn{4}{|c|}{ 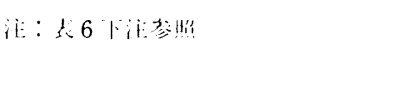 } & & \multicolumn{3}{|c|}{$\begin{array}{ll}\text { - : 有意差無し } & (\alpha=0.05) \\
+ \text { : 有意着有り } & (\alpha=0.05) \\
\text { \# : 有意着们り } & (\alpha=0.01)\end{array}$} \\
\hline
\end{tabular}

表 10 各種印象材におけるトレー間の $\mathrm{t}$ 検定（モデル C ）

ALG

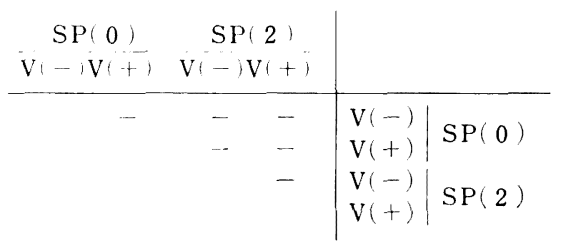

SIL

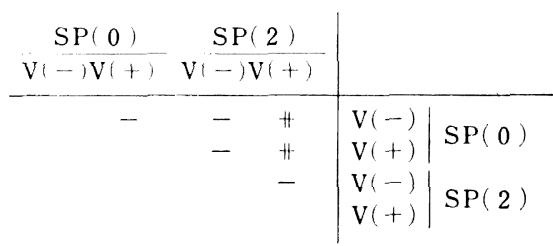

注：蒜6下注参照

象材を盛ったトレーの圧接速度と，印象材の硬化まで卜 レーを定位置に保持する保持圧が，印象材におよぼす影 響と顎粘膜を想定したウレタンラバーの被圧変位による 影響が複合されている。そこで，顎粘膜としてのウレタ
RUB

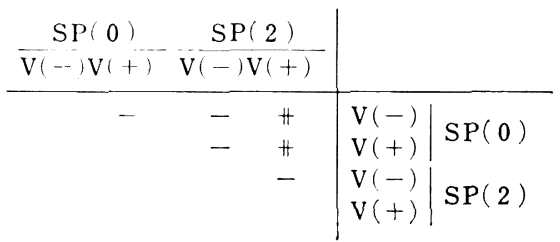

一：柱意差無し $(\alpha=0.05)$

+ : 们意羔有り $(\alpha=0.05)$

\#：有意着有り $(\alpha=0.01)$
ンラバーを接着せず平滑なエポキシレジンのモデル Gを 用いて, 印象材およびトレーの相違が計測模型の寸法精 度におよぼす影響を把握するため, コントロールとして 用いた。 
表 11 各種トレーにおける印象材間の $\mathrm{t}$ 検定（モデル C)

SP(0)V(-)
\begin{tabular}{ccc|c} 
ALG RUB & S I L & \\
\hline & - & - & ALG \\
& & - & RUB \\
& & S IL
\end{tabular}

$\mathrm{SP}(2) \mathrm{V}(-)$

$\mathrm{SP}(0) \mathrm{V}(+)$

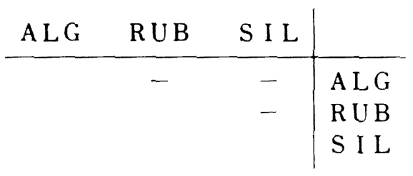

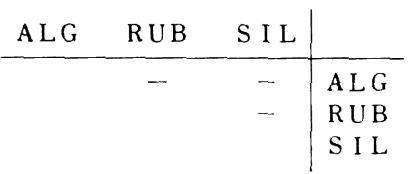

$\mathrm{SP}(2) \mathrm{V}(+)$

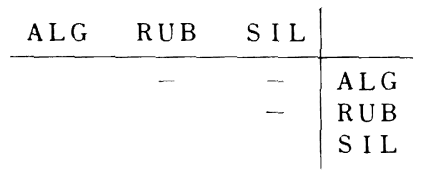

注：表6下注参照

- : 有意差無し $(\alpha=0.05)$

+ ：有意差有り $(\alpha=0.05)$

\# : 有意差有门 $(\alpha=0.01)$

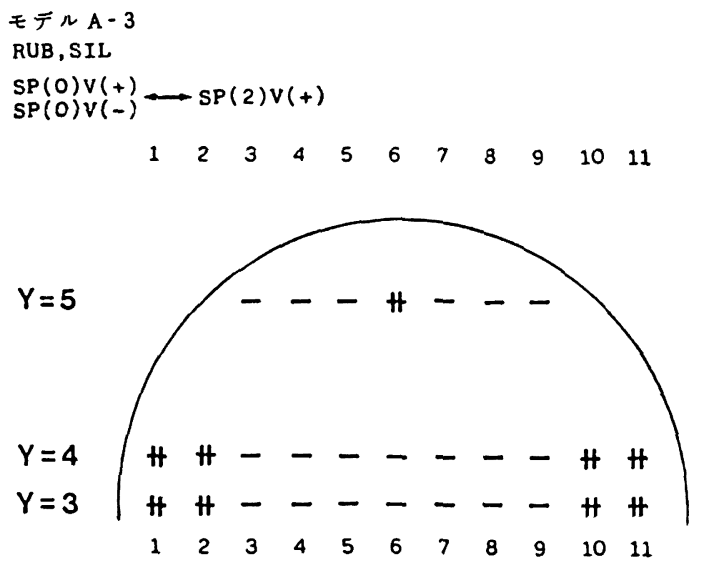

一:有意差無し $(\alpha=0.05)$

+ :有意差有 $b(\alpha=0.05)$

注图9 下注照

\#:有意差有 b $(\alpha=0.01)$

図13トレーの組合わせにより有意差を示した部位

本研究で使用したシミュレーションモデル A-3 およ びCを生体の頻堤および口蓋粘膜と比較検討してみる と, シミュレーションモデルの常用荷重量における局所 被圧変位量は生体の㴿粘膜でその䫇粘膜厚径の約 $1 / 3$ と 報告した岸 ${ }^{22}$ )に近似していた（表 1)。しかし，常用荷重 量までの荷重量一変位量は図 15 に示すように, 無歯䫛 䫟粘膜を測定した宮下 ${ }^{10)}$ と異なった曲線を示した. 特 に, 荷重量が小さいとシミュレーションモデルは小さい
值で，トレ一保持圧 $\left(0.51 \mathrm{~g} / \mathrm{mm}^{2}, 1.0 \mathrm{kgf}\right)$ において, シミュレーションモデルのウレタンラバーの変位は小さ な値となった。 そのため, シミュレーションモデルは生 体の颖粘膜と直接比較はできないが，これら常用荷重量 下での局所被圧変位量と常用荷重量までの局所被圧変位 量の相違点 (図 15) を考虑すれば，これらシミュレーシ ョンモデルで十分と考え本研究に使用した。 

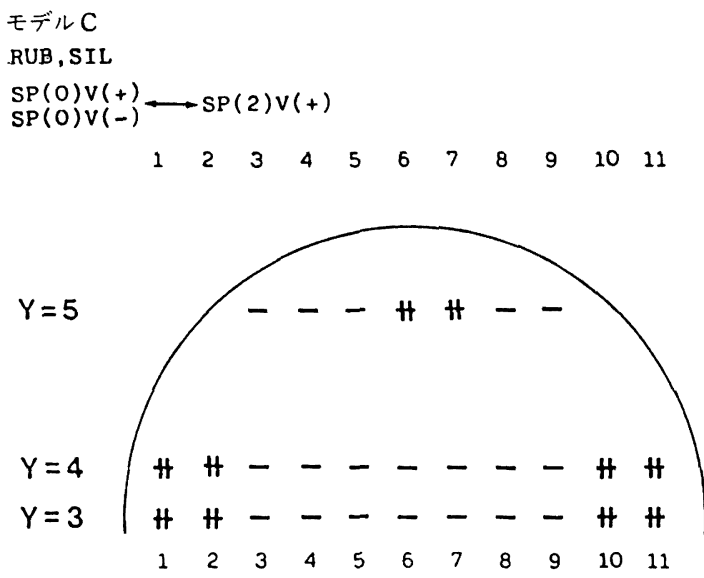

図 14 トレーの組合わせにより有意差を示した部位

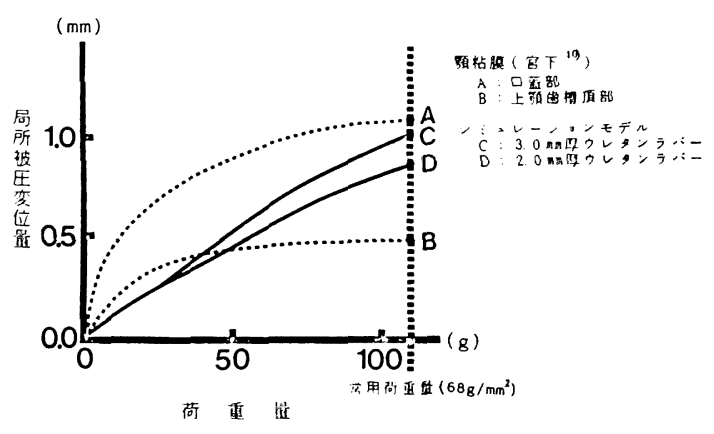

図 15 局所被圧変位量の比較

\section{2. トレー}

トレーに設定したスペーサー，ストッパーおよびベン トが模型の寸法精度に影響を与えるとの報告は多くあ る.

クラウンブリッジや局部床義歯の印象採得は残存歯に ストッパーを設定し，トレーの位置および印象材のスペ 一スを付与できる。しかし，被圧変位性を有する䫛粘膜 で覆われている無歯顎々堤の印象採得はストッパーを額 粘膜上に設定し，スペーサーを付与したトレーを用いな ければならない。そのため，ストッパーはトレーの位㯰 確保に役立つが, 口腔内に㭔入し, 顎堤の所定位直に圧 接するまでのトレー圧接速度とトレーを介したストッパ 一部へのトレ一保持圧は顎粘膜に変位をおこし, 作業模 型の形態に影響を与えると考えられる. ストッパーとス ペーサーを設定しないトレーに印象材を盛り, 影堤に圧 接するときのトレー圧接速度と保持圧は未硬化の印象材
を顎堤に㳂って流動させる。その一方，圧接までのトレ 一圧接速度と保持圧によって生じる印象材の内圧は, 顎 粘膜および硬化後の印象材に影響を与えるものと思われ る. ストッパーとスペーサーについて有床義歯を対象と した報告は少なく，藤城 ${ }^{33)}$ は無歯顎々堤として金属原型 を使用し，ストッパーを額堤外に設定し，スペーサー (3 mm) を付与しているため，ストッパーと被圧変位性 を有する顎粘膜の関係は検討していない.

著者は無歯顎々堤を検討対象とするためには，顎粘膜 上にストッパーを設定し，トレーの位置関係を定め，ト レ一圧接速度と保持圧がトレーを介して印象材と影粘膜 に与える影響を検討寸べきと考えた．そのため，本研究 ではストッパーとスペーサーの有無が，印象採得から得 られた作業模型に与える影響を検討するため, シミュレ ーションモデル（モデル A-3，C）上にストッパー（長さ $10.0 \mathrm{~mm} \times$ 幅 $10.0 \mathrm{~mm} \times$ 厚さ $2.0 \mathrm{~mm}$ ) を設定したトレ ーとストッパー無トレーを用いた.

ベントについて, 溝上ら ${ }^{34)}$ はラバーベース印象材のイ ンジェクションタイプを用い, ベントの直径 $2.5 \mathrm{~mm}$ 以 下では印象材がトレーから落下しないと述べ，三間坫は シリコーン連合印象においてスペーサー $(2.0 \mathrm{~mm})$ とベ ント（直径 $1.0 \mathrm{~mm}$ ）を併用すると印象材の残留応力が 減少し, 寸法変化が小さくなると述へ, 印象採得時に卜 レーのベントの影響が考えられる，そこで，著者はトレ 一のベント有無が印象採得から得られた計測模型に与え る影響を検討するためトレーにベントを直径 $2.5 \mathrm{~mm}$, その間隔を $2.5 \mathrm{~mm}$ で配置したベント有りトレーとベン 
ト無しトレーを用いた.

\section{3. 即象採得}

日常臨床ではトレーを口腔内の所定位置に圧接する と, トレー内の印象材は口腔内の顎堤および歯肉煩移行 部など全般的に広がり，その後，トレ一圧接時ほどの圧 は必要とせず，ほぼ一定の保持圧で印象材の硬化を待つ ことになる. 従来, 印象採得についてトレーの口腔内圧 接時にトレーが受ける印象圧から観察が多く行われ, こ の印象圧に影響をおよぼす因子として顎堤形態，トレー 形態, トレー圧接速度および印象材の流動性があげられ る $^{1,2,36)}$. そして, トレー圧接速度に関して, 関根ら ${ }^{2)}$ 金属円板トレーを用い，圧接速度を 1 $5 \mathrm{~mm} / \mathrm{sec}$. と変 えて各種印象材を介してトレーが受ける圧を測定し「ト レ一圧接速度が速くなるに伴って，印象材の内圧は大き くなる傾向が認められた」と報告している.塩川ら ${ }^{36)}$ も アクリルレジン製の円柱を印象材の入った有孔管状トレ ーに 10,50および $100 \mathrm{~mm} / \mathrm{min}$. の押し込み速度で行 い「押し込み速度が速くなると押し込み力の増加も急に なる傾向がある」と述べている。これらの報告はトレー 圧接速度の重要性を述べているが，トレーの圧接速度に ついては臨床検討を行っていない，そこで，著者は臨床 でのトレー圧接速度を検討するため, トレーハンドル部 にLEDを取り付け，本研究に使用した印象材を盛った トレーを口腔内に插入し，所定位置まで圧接するときの トレー压接速度をサホンビジトレーナー（東京齿材社, CII）で測定したところ平均 118.0 (SD : 24.8) mm/ min. であった。 この值を参考としてトレー压接速度を $100 \mathrm{~mm} / \mathrm{min}$. に設定した.トレー圧接後のトレー保持に ついて，松元 ${ }^{37)}$ は「通常の臨床において，患者の口腔内 でどれくらいの指圧でトレーを保持しているかを大略測 定してみたところ, 約 $1 \mathrm{kgf}$ であった」と述べている. この報告を参考とし，トレーの保持圧は $0.51 \mathrm{~g} / \mathrm{mm}^{2}$ $(1.0 \mathrm{kgf})$ とし, 保持トレー速度を $0.05 \mathrm{~mm} / \mathrm{min}$. に設 定したが，トレーの保持時閒内の位置変化はほとんどな いと思われる.

以上から，印象採得はトレーの圧接と保持を分けて観 察するために，トレーを一定速度 $(100 \mathrm{~mm} / \mathrm{min}$.$) で所$ 定位置まで圧接し, その後, 印象材の硬化まで一定の保 持圧でトレーを保持する臨床操作を考虑した方法で行っ た.

\section{4. 計測方法}

印象採得から得られた模型の寸法変化について, 金属 原型上に標点を設け模型上に再現された標点間距離の比

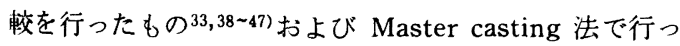

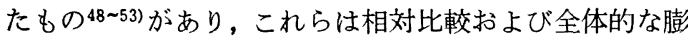
縮変化率で検討している。 しかし，無歯䪽々堤の印象採 得から得られた模型を検討するには不十分と考えられ る。そのため，第 1 報 ${ }^{23)} に$ 報告したごとく，計測基準を シミュレーションモデル，および計測模型外に設定した 三次元位置再現装置と三次元座標測定機を用いることと した.

\section{II. 計測模型について \\ 1. モデル $\mathrm{G}$}

顎粘膜としてのウレタンラバーを接着していない $\mathrm{G}$ イプの印象採得によって得られた計測模型は，印象材と トレーの影響を観察するためにコントロールとして用い た.

ALG による計測模型の Y3 および Y4 において, 各ト レーは中央部を頂としたゆるやかな凸状を示した。この 傾向を金属原型を用い, アルジネート印象材，トレー形 態および模型材が上頷模型寸法精度におよぼす影響を検 討した藤城 ${ }^{33)}$ と比較すると, 前頭断面における前歯部で あまり差を認めなかった。しかし， 臼歯部で顎堤が内側 に傾斜し，顎堤間の中央部がやや凹状で著者の成績と逆 の傾向を示した．藤城は凹状になった理由として「模型 の寸法精度に対する最も大きな因子は模型材の各方向人 の膨張とその抑制によるもの」としている．著者の計測 模型の厚さはほぼ均一であるが, 藤城の模型は顎堤部と 中央部で差があり，この形態の相違が模型材硬化時に影 響したと考えられる。スペーサーとベントの影響をみる と, トレー SP (2) V (+)がシミュレーションモデル に最も近い值を示し, トレー SP (2) V (ー), トレーSP (0) V (+), トレーSP (0) V (ー) の順であり, スペー サーとベントとが模型の寸法精度におよぼす影響を検討 した藤城と同様な傾向を示した。これはトレーのスペー サーにより，トレー内に生じたアルジネート印象材の内 圧が緩和されたためと考えられる。

RUB による計測模型は各 Y 断面において, 各トレー はALGよりもゆるやかな凸状となり，トレー間による 差はALG ほど認められず，スペーサーとベントの影響 は認められなかった。この理由として，ポリサルファイ ドラバー印象材は，内部応力に対する緩和能力が高いと 報告した川上坾のとおりに，この印象材を用いると印象 採得時のトレー圧接速度と保持圧により, トレー内の印 象材の内部応力を緩和したためと考えられる.

SIL による計測模型は各Y断面において, RUBよりも さらに平坦であり，トレー間による差は認められず， ス 


$$
128-336
$$

ペーサーとベントの影響も認められなかった，金属原型 を各種トレーでシリコーン連合印象し，印象材の内圧と 模型の寸法精度を検討した三間 ${ }^{35}$ は，スペーサーの影響 が大きく，特に両者の併用による模型の寸法精度が，最 も良好であったと述べている。この理由として，三間は 金属原型周囲の高いトレー密接性を実験条件としている ため, ベントおよびスペーサーの影響が著明であったも のと推察される. しかし, 臨床に扔いて, トレ一辺縁と 䫟堤周縁粘膜とは必ずしもこれほど密接していないた め,このように著明な影響はないものと思われる。

各種印象材についてトレー間で有意差 $(\alpha=0.05)$ は 認められず，また，各トレーについて印象材間でも有意 差 $(\alpha=0.05)$ は認められなかった. トレー形態と印象材 の影響を検討した藤城 ${ }^{33}$ は, 模型間の一部に有意差 （ $\alpha=0.05,0.01 ）$ を認めたと報告している. しかし，藤 城はトレー辺縁形態の相違による影響を主として観察し ていたためと推察される.

最もシミュレーションモデルに近い計測模型が得られ た印象材はシリコーン印象材であり，ポリサルファイド ラバー印象材, アルジネート印象材の順であった。

以上から，平坦で被圧变位性が無く硬い印象対象物を 印象採得するとき, 印象材の種類（アルジネ一ト印象 材，ポリサルファイドライバー印象材およびシリコーン 印象材) 打よびトレー（スペーサーおよびベントの有 無）などを考慮する必要性がないことを示唆している.

\section{4. モデル $\mathrm{A}-3$}

モデル A-3 は印象採得によって，無歯影顎粘膜がい かなる状態で再現されるかを検討するために，被圧変位 性を有寸るウレタンラバーを厚さ $3.0 \mathrm{~mm}$ で均等に接着 したものである.

ALG による計測模型の各 Y 断面において, トレー $\mathrm{SP}(2) \mathrm{V}(+)$ はストッパー設定部位に著明な凹状を示 した。これらはスペースを確保するストッパーの影響が 著明に認められ，シミュレーションモデルよりマイナス の值を示した。 また，シミュレーションモデルにより近 い傾向を示し、スペースの影響から認められた。ベント の影響についてみると, スペーサー無しのトレーでは影 響を認めなかったが，スペーサー有りのトレーにベント を付与すると，計測模型はシミュレーションモデルに近 くなる効果を認めた。これまで被圧変位性を有するシミ ユレーションモデルを用いて，印象採得時の諸条件が模 型の寸法精度におよぼす影響について，基礎的に検討し たものは見当らない，部分欠損の被験者に 2 種のトレー を用いて，印象圧（約 $9 \mathrm{kgf}$ ） と印象面形態の関係を臨
28 巻 2 号 (1984)

床検討した平井 ${ }^{21)}$ は，スペーサー無しの強密接様式の卜 レーが，スペーサー有りの弱密接様式よりも2〜4倍の 変位量を示し，著者の成績と同様にスペースの影響を報 告した. トレーSP (0) において, ALG, RUB および SILの平均值はほぼ等しかった.

各印象材についてトレー間では, トレー SP (2) V (+) とトレー SP (0) V (-) およびトレーSP (2) V (十) とトレーSP $(0) \mathrm{V}(+)$ 間でストッパー設定部位 にのみ（図 12,13$)$ 有意差 $(\alpha=0.05,0.01)$ が認められ た. ベント有無による有意差 $(\alpha=0.05)$ は認められな かったが，スペーサー有りのトレーでは，印象材間でス トッパー設定部位に $40 \sim 50 \mu \mathrm{m}$ の差を示した.この理 由として, トレーを压接し, 一定の保持圧でトレ一保持 を行うと，保持圧はストッパー部，印象材を介してシミ ユレーションモデルに加わる. しかし, 溝上ら ${ }^{34)}$ の報告 のごとく, 印象材はフローを有する間, その圧に応じて 主にベントから流出するので, ストッパーがシミュレー ションモデルを変位させるものと考えられる. 一方, ベ ント無しのトレーでは，ストッパーとその周囲の差は小 さかった.これは, 印象材の流出が妨げられ, トレ一内 の印象材の内圧が大きくなり，シミュレーションモデル のストッパー以外の部位を変位させたと考えられる。

最もシミュレーションモデルに近い計測模型が得られ たトレーはトレー SP (2) V $(+)$ で, ついでトレーSP (2) V (-), トレーSP $(0) \mathrm{V}(+)$ とトレー SP $(0) \mathrm{V}$ (一) はほぼ同じ值を示した。

各トレーについて印象材間では，有意差 $(\alpha=0.05)$ は認められなかった。最もシミュレーションモデルに近 い計測模型が得られたのはアルジネート印象材であり, 他の印象材はほぼ同程度であった。

以上から, 平坦で均一な被圧変位性を有する印象対象 物を印象採得するとき，ストッパー設定部の変位を考庵 してスペーサー有りのトレー使用が最も好ましいことを 示唆している.

3. モデルC

モデルC はモデル A-3 と同じ平坦な表面形態を有す るが，顎骨を想定したエポキシレジンを凸型に成型し， ウレタンラバーを厚さ 3.0 拈よび $2.0 \mathrm{~mm}$ として被圧変 位量を変えたものである。

ALG による計測模型の各 Y 断面において,トレーSP （2）は中央部でモデル A-3 より著明な凸状 $(40 〜 50 \mu \mathrm{m})$ を示し，ストッパー設定部位でモデル A-3 より著明な 凹状 $(-25 \sim-80 \mu \mathrm{m})$ を示した.これは㖽骨を想定し たエポキシレジンが凸型のため，ストッパー設定部位へ 
の加压が顎粘膜を想定した被圧変位性の高いウレタンラ バーを凹状に変位させ，さらにシミュレーションモデル 中央部をプラス方向へ凸状に変位させたと考えられる。 モデルCではベントによる影響は認められなかった．そ のため, モデル A-3 ではスペーサー有りトレーにベン 卜を付与すると, その効果が認められるので, 頭粘膜の 被圧変位性および颌堤形態によりベントの効果が異なる と推察される.

トレーSP (0) は各 Y 断面において, シミュレーショ ンモデル周縁にゆるやかな凹状を示しシミュレーション モデルよりもマイナスの值であった.

臨床的に検索した平井 ${ }^{21)}$ が報告したごとく「印象材に よる加圧によって粘膜が変位する場合に中央部の組織の 側方移動性は少なく, 周縁部に移るに従って側方移動性 が多くなる」ためではと推察される.この傾向がモデル Cでモデル A-3 より著明に現れた。 これはモデルCの 中央部が小さい被圧変位量のためにトレ一圧接時および 保持時にトレーから加わる圧は大きな圧となり，トレー 中央部の印象材を被圧変位量の大きな周縁部へと流動さ せ，変位させたと考えられる。この傾向はベントを付与 しない場合, やや大きかった. トレーSP (0) ではベン トの有無による著明な差は認められず, ともにシミュレ ーションモデルに近い值が得られた。

RUB および SIL による計測模型はほぼ同じ值で ALG よりも5〜25 $\mu \mathrm{m}$ 大きな值を示した. しかし, ALG と同 様の傾向を示した. モデル A-3 において, ALG は他の 2 種印象材間に差が認められなかったことから検討する と, シミュレーションモデルの形態の相違が, トレー圧 接時に流動性の少ない ALG において著明であったと考 えられる。

各印象材についてトレー間で㳉, トレー SP (2) V (+) とトレー SP (0) V (一) 扔よびトレー SP (2) V (+) とトレーSP $(0) \mathrm{V}(+)$ 間でストッパー設定部位 にのみ（図 14）有意差（ $\alpha=0.05 ）$ が認められた. ベン 卜有無による有意差 $(\alpha=0.05)$ は認められなかったが, スペーサー有りのトレーでは，印象材間でストッパー設 定部位に約 $50 \mu \mathrm{m}$ の差を示した。これはモデル A-3の 場合と同じ理由によると思われる.

各トレーについて印象材間では，有意差 $(\alpha=0.05)$ は認められなかった. 最もシミュレーションモデルに近 い計測模型が得られたのはアルジネート印象材であり， 他の印象材はほぼ同程度であった。 モデル A-3 同様ア ルジネート印象材とビニルシリコーンおよびポリサルフ アイドラバー印象材間にやや差が認められた。これは印
象材の流動性とシミュレーションモデルの相違によると 考えられる.

以上から，トレー中央部に相当する顎粘膜の被圧変位 量が周縁部と比べて小さい印象対象物を印象採得すると き，スペーサー無しのトレー使用が好ましいことを示唆 するものである

\section{第 5 章 結 論}

無歯顎顎堤と顎粘膜を想定したシミュレーションモデ ルと三次元位置再現装置を用いて, 総義柬調製過程にお ける印象採得時にシミュレーションモデル, トレー（ス ペーサー, ベント) および印象材の相違が作業模型にお よぼす影響について三次元的に検討した結果，以下の結 論を得た。

1. 被圧変位性の無いシミュレーションモデル Gタイ プより得られた計測模型はトレーおよび印象材の相違に よる影響は認められなかった。

2. 均等な被圧変位量を有するシミュレーションモデ ル A-3 タイプより得られた計測模型は,トレーの相違 による影響を認めたが印象材では認められなかった．最 もよい組合せはスペーサーおよびベント有りのトレーに アルジネート印象材を用いた場合であった。

3. 部位により被圧変位量が異なるシミュレーション モデルCタイプより得られた計測模型は，トレーの相違 による影響を認めたが，印象材では認められなかった。 最もよい組合せは，スペーサーおよびベント無しのトレ ーにアルジネート印象材を用いた場合であった。

4. 以上から，有床補緅臨床の印象採得において，被 圧変位性の少ない軟組織のときはトレーおよび印象材を 考慮する必要が少ない。しかし，被圧変位性の大きい軟 組織のときは，印象材への配慮よりもトレーへの考虑を 十分に行う必要がある。

本研究の要旨は, 昭和 57 年度日本補経歯科学会関東支部学術 例会 (昭和 57 年 6 月), 第 69 回日本補緅歯科学会学術大会 (昭 和 57 年 11 月）に扔いて発表し，会誌に抄録在掲载した。

稿老終わるにあたり，本研究に際し終始ご兓篤なるご指導お よびご校閲在賜りました日本大学歯学部 森谷良彦教授また ご専攻の立場からご指導を賜りました日本大学歯学部大木一三 教授，小野瀬英雄教授，大橋正敬教授，五十嵐孝義教授に深く 感謝の意を表します.

あわせて, 日頃ご助言ご靴撻を頂きました日本大学歯学部 総 合歯学研究所歯科材料研究室 土生博義助教授，歯科補緅学第 
1 講座 祇園白信仁助手, 山本克之助手, 医局員ならびに大学 院生各位に対し感謝の意を表するとともに，本研究に多大なる ご協力を頂いた(株)デンテック木村 誠氏，角田富夫氏に厚く お礼申し上げます。

\section{Summary}

An impression in denture prosthodontics is the first step for the construction of full denture.

An impression is in clinic so important that the prognosis for denture is depended upon. Therefore, a conside rable amount of reaserch has been reported. Especially, the soft tissue as an impression objectives can be displaced under pressure so that the method in edentulous impression making has influence on contour variations of the master cast.

According to the impression, it is supposed that the adaptability to denture goes down and the basal soft tissue is injured in function. Basic and clinical studies on the edentulous impression have been considered, how ever, it seems not to arrive at evidence conclusion.

The basic study (Part. 1) was designed for the sake of how to make impression for the functional denture without injury to edentulous patient. As the result of this study, the simulation model supposed edentulous alveolar ridge and three dimensions repositioner were made. Then, three dimensional measurement system to compare simulation model with master cast was reported and published.

In this study, the three dimensional measurement system and simulation model as the alveolar ridge are used for impression in denture construction. It is investigated with the three dimensional measurement system that impression tray (spacer, vent), impression material and these combination are influenced on the reproductiv. ity of simulation model.

The conclusions are follows:

1. The cast from the simulation model type $G$ without displaceability, is not influenced by impression tray and impression material.

2. The cast from the simulation model type A-3 with constant displaceability, is not influenced by impression material but by the impression tray. The best cast is produced by the impression used the tray (spacer, vent) with alginate impression material.

3. The cast from the simulation model type $\mathrm{C}$ with difference displaceability in part, is only influenced by impression material. The best cast is produced by the impression tray without spacer and vent using alginate impression material.

4. From these conclusions (1-3), when the impression for the denture construction is made of the soft tissue with the poor displaceability, the impression tray and material are not so important. However, for the soft tissue with the rich displaceability, it is necessary that the impression tray is more considerable than material.

\section{文献}

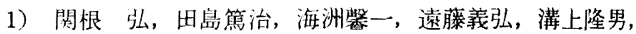
平井泰征 : 有床義歯のための印象方法に関する基磷的な らびに臨床的研究 (第 1 報), 印象材の内圧および流動 状態について，補緅誌，10：107～113，1966.

2) 関根 弘, 田白篤治, 蔧上隆男, 海洲整一, 平井泰征, 前田佳英, 大沢一博：有床義菌のための印象方法に関寸 る基礎的ならびに臨床的研究 (第 2 報)，印象材の内圧 上トレー王接速度抽よび流動路との關倸について, 歯学 報, $71: 2161 \sim 2166,1971$.

3）伎久間孔毅：無歯罰印象採得のレオロジーによる検討, 齿材器誌, $12: 79 \sim 124,1965$.

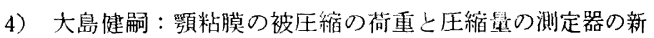
考案, 日大歯学, $40: 231 \sim 232,1966$.

5）大島健嗣：枵粘膜の被圧縮の荷重と圧縮量の新開発の測 定装置，補緅誌，10：51～56, 1966.

6）大島健嗣：ヒトの䅡粘膜の被圧縮の荷重と圧縮量に関寸 る研究 (第 3 報)，日大齿学，41:335 336, 1967.

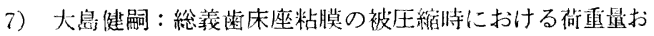
上び圧縮量に関士る研究, 補緅誌, 12：245 286, 1968.

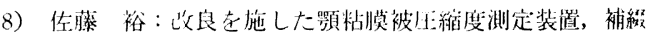
誌, $8: 60 \sim 66,1964$.

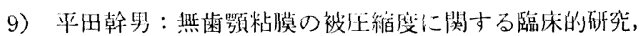
補緅誌, $3: 14 \sim 27,1959$.

10）宮下恒太：影粘膜の局所被庄变位度と咬台力に上る義䛧

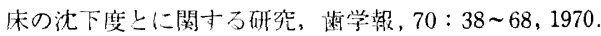

11) Boucher, C.O. : Studies of Displacement of Tissues Under Dentures, J. Amer. dent. Ass., 27 : 1476 1478,1940

12) Sohm, H. : Untersuchungen über die Kompressibi lität der Gaumenschleimhaut bei senkrechter $\mathrm{Dr}$. uckeinwirkung, Zschr. Stomatol., $32: 202 \sim 217$, 1934.

13）王中资郎：口蓋粘膜のクリープに関する研究，補緅誌， $16: 358 \sim 379,1973$. 
14）三輪英則：断続荷重による口蓋粘膜のクリープ，補 経 誌, $20: 399 \sim 422,1976$.

15）佐藤志責 : 口蓋粘膜のクリープと荷重量との関係 : 補緅 誌, $23: 103 \sim 125,1979$.

16）中島俊郎：口蓋粘膜の忘力緩和に関する研究：補緅誌, $19: 391 \sim 410,1975$.

17) Frank, R.P. : Analysis of Pressures Produced during Maxillary Edenturous Impression Procedures, J. prosth. Dent., $22: 400 \sim 413,1969$.

18）梅原正年：各種印象材による口蓋粘膜の圧縮変形を立体 写真測量法によって観察する, 歯学報, $63: 1 \sim 25$, 1963.

19) Woelfel, J.B. : Contour Variations in Imprssions of One Edentulous Patient, J. Prosth. Dent., 12 : 229 254, 1962.

20）黑田昌彦：義歯休下粘膜の負担圧の分布状態に関する実 験的研究, 歯学報, $71: 1445 \sim 1474,1971$.

21）平井泰征：有床義歯における印象時の粘膜の被圧状態が 印象面形態に及ほ方影響に関する実験的研究, 歯学報, $71: 1835 \sim 1868,1971$.

22）田中 淳：印象圧の相違が䅡粘膜形態扩上び咬合力に及 ほす影響に関寸万研究一下筫片側性遊離端義歯につい て一, 補緅誌, $26: 455 \sim 471,1982$.

23）星野亨, 潤米宏仁, 久保田幸生, 泉田一藏, 田島直 孝, 山田博明, 山本克之, 祇園白信仁, 森谷良彦: 印象 採得法の基礎的検討, 第 1 報 シミュレーションモデル と三次元位置再現装置について， 補 緅 誌，27：759 766, 1983.

24）岩尾 微 : 三次元測定器による中型間接法模型の膨縮精 度に関寸る研究 (第 1 報)，三次元測定機の有用性の検 郭, 歯材器誌, $34: 136 \sim 147,1977$.

25）稻葉 繁, 是沢恵三, 荻原重一, 鐘ヶ江修, 川名孝義,

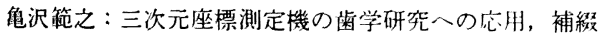
誌, $25: 55 \sim 60,1981$.

26）川名孝義：下上顎歯牙の Overlap 量上侧方位歯牙接触 様式について一三次元座標测定機による研究一，歯学, $68: 763 \sim 787,1981$.

27）象沢範之：上下顎臼歯における咬頭頂之咬合面窩の対向 関係について一三次元座標測定機による研究一，歯学, $68: 788 \sim 805,1981$.

28）栈 淑行, 石塚 享, 小泉政幸, 羽田京太郎, 富田 豊, 長島信也，松本幸士，崔 大均，生司喜則，㕕田 成， 八木庸行, 五十嵐孝義 : 診療姿勢が支台歯形成面形態人 及ぼす影響について (第 1 報)，補緅誌，26：311～322， 1982.

29）土生博義，平口久子，小林孝誌，田辺直紀，茂木孝之， 三次元座標測定システムの迷科材料研究への応用（第 1
報)，装置の概要と測定精度，日大歯学， $56: 914 \sim 920$ ， 1982.

30）鈴木 章：歯列模型の寸法精度に関寸る基礎的研究，歯 学, $71: 449 \sim 474,1983$.

31）羽田京太郎, 富田 豊, 守屋義雄, 津江明伸, 行田克 則, 高橋章浩, 中沢 清, 東風 巧, 大島修一, 牟田 成, 五十嵐孝義：歯科万う着に関する研究(第 4 報), 補緅誌, 27 : 943 956, 1983.

32）岸 正孝：歯槽堤粘膜の被圧変位性に関する加圧面の面 積と変位量との関倸についての実験的 研究, 歯学 報, $72: 1042 \sim 1071,1972$.

33）藤城鉄英：哿慔型の寸法精度に䦥する研究，補 綴誌， $18: 382 \sim 402,1975$.

34）清上隆男, 小平 崇, 名波智章, 林 甫, 西孝一, 栂安秀樹, 田中 彰, 竹内良一: 義歯床基礎面の印象に 関寸る臨床的考察（第 1 報），一各個トレ一の遁出孔の 大きさについて一, 歯学報, $78: 133 \sim 140,1978$.

35）三間清行：シリコーン印象法における印象圧の寸法精度 に及ぼす影響について, 補経誌, $21: 579 \sim 602,1977$.

36）塩川延洋, 宮川修, 中野周二：印象採得法と印象材の 粘弾性, DE, 20:1 15, 1972.

37）松元 誠: 遊離端義歯咬合構成の臨床, 初版, 151 170, 医蔽薬出版, 東京, 1980.

38）草刈玄, 村山正史, 高瀬和喜, 塩屋雅晴, 水落 功, 吉田 真: シリコーン連合印象の寸法精度, 第 1 報 印 象方法抢上び印象材に上る検討, 補緅誌, $17: 214 \sim 222$, 1973.

39）草刈立, 高瀬和喜, 村山正史, 塩屋雅晴, 吉田 藏, 綿谷修一：シリコーン連合印象の寸法精度, 第 2 報 シ リコーン印象材の理工学的性質との関連, 補緅誌, 17 454 461, 1974.

40）松代浩明, 佐野敬一, 松代隆良, 奥野善彦: 印象撤去速 度がアンダーカットの印象精度に及ぼす影響, 阪大歯 誌, $17: 134 \sim 142,1972$.

41）金沢俊文：歯列模型ならびに久損歯列模型の寸法变化に 関する研究, 補綴誌, $22: 385 \sim 406,1978$.

42）大輪正昭，西山 䐝，成松賢二，豊間 均，小谷 誠， 氏家临明, 砂川孝, 小山田勝彦, 大木一三: 印象材の 厚さ掞よび支台歯形態の相違が模型用埋没材の硬化膨張 に及ぼす影響について, 補緅誌, $20: 13 \sim 23,1976$.

43）大輪正昭：冠・架橋義齿調製時における模型用埋没材の 硬化膨張に関する研究，一各個トレー形態の相違による

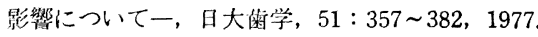

44）川和忠治: シリコーン印象の精度に関する研究, 第 2 報 支台歯の寸法精度に対する隣在歯の影響, 補経誌, $19: 158 \sim 169.1975$.

45) Harris, W.T. Jr. : Water Temperature and Accu 
racy of Alginate Impressions, J. prosth.Dent., 21 : $613 \sim 617,1969$.

46) Podshadley, A.G., Dilts, W.E., Neiman, R. and Ellison, E. : Accuracy of Relined Mercaptan-Rub. ber Impressions, J. prosth. Dent., $24: 503 \sim 511$, 1970.

47) Skinner, E.W. and Hoblit, N.E. : A Study of the Accuracy of Hydrocolloid Impressions, J. prosth. Dent., 6: 80 93, 1956.

48）野川 勇：間接法作業模型の寸法精度に影響する因子に つて,チオコール・ラバー印象材ならびにシリコー ン・ラバー印象材による方法, 歯学, $56: 148 \sim 166$, 1968.

49）野田 敬：間接法作業模型の寸法精度に影響する因子に ついて,アルギン酸塩印象材に上る方法, 歯学, 57 :
$181 \sim 199,1969$.

50）初道守久：架工義歯製作時における間接作業模型の寸法 精度に影響する因子について，歯学，61：350 371, 1973.

51）川和忠治：シリコーン印象の精度に関する研究，第 1 報 单独支台歯の寸法精度, 補綴誌, $19: 138 \sim 157,1975$.

52) Stackhouse, J.A. Jr. : The Accuracy of Stone Dies made from Rubber Impression materials, J. prosth. Dent., $24: 377 \sim 386,1970$.

53) Mitchell, J.V. and Damele, J. J. : Influence of Tray Design upon Elastic Impression Materials, J. prosth. Dent., $23: 51 \sim 57,1970$.

54）川上道夫, 長谷川二郎, 太田克子：チオコールゴム印象 材の压接時に発生する応力とその緩和, 歯理工誌, 6 : $17 \sim 20,1966$. 